\title{
Thoughts on the Right Transfer Issues of Farming Land
}

\author{
Furong Song \& Lifeng Dong \\ Geography Department, Binzhou College \\ Binzhou 256603, China \\ E-mail: bzsfr@163.com
}

The research is financed by the Education Department of Shandong. No. j08we67 (Sponsoring information)

\begin{abstract}
Farming right transfer of land is an inevitable consequence of the economic development in agriculture. It is the nation's endeavor towards modernized and large scale agriculture production that drives the farming right transfer of land. This paper analyzes the causes that starts the trend of farming right transfer, identifies the issues in the present practice of the farming right transfer, the issues such as practice lack of formality, a system lack of proper mechanism and regulation. Based on the study, the paper also presents some suggestions and advices to how to manage the farming right transfer.
\end{abstract}

Keywords: Agricultural modernization, Farming right transfer, Land use right

\section{Introduction}

The keys to ensure farmers' long term right on land, generate enthusiasm from farmers, guide and motivate farmers to focus on the effort towards modernization of agriculture, are to promote innovation in land regulation system, introduce market mechanism into land contraction between farmers and government, and establish the market-oriented contraction and right transfer system for land use. In recent years, with the shift of agricultural structure, growth of the second and the third rural industries, labor force migration from countryside to cities, the right transfer of land has showed a trend of accelerated speed.

\section{Current issues in the right transfer of land}

The right transfer of land is driven by the rural economic development and it reflects the objective demand from ever increasing productivity. It pushes the shift of agricultural structure and business-like operation, drives operation to a proper scale, increases agriculture investment and broadens the channels of income. However, problems exist which can not be ignored.

1.1 None-regulated practices.

At present, the mechanism for transferring right has not been completely established. Many problems exist in completing the mechanism and standardizing the procedures. Instead of following law, regulation and procedure, many farmers rely on verbal agreement in private transfer. Such actions fail to enforce the rights and obligations between parties and potentially lead to serious problems.

\subsection{Lack of fully functional intermediary organization}

So far, most areas do not have regulated market mechanism for transferring the right of land, severely lack of intermediary organizations of land transfer, and lack of channels for information flow. Although some local authorities established intermediary organizations, it is rare that these organizations facilitate transfers 
following market principles and following law. Poorly developed market, lack of intermediary organization and lack of information flow often lead to the failure in which farmers intended to give the land right hardly find suitors to acquire the rights, while the farmers trying to get land right can not find anyone to acquire from. The situation in turn impacts the flow and optimal allocation of critical production elements.

\subsection{Improper government role in land transfer}

Some local authorities play dominant role in land transfer, showing no respect to farmers' intention, arbitrarily changing the lease contract and engaging in forced land transfer. Some take the land transfer as a way to increase local authorities' income; some take it as a way of showing off local political achievement at the cost of local farmers' interest. Some local authorities take policy of "back-leasing" and "sub-contract" (leasing back the land that is not properly farmed and sub-contracting to individuals who could use the land more efficiently, noted by translator). Due to different motivations and practices, some of these misinterpret or even violate laws and regulations related to land, such as forced "back-leasing", under compensation, "back-leasing" for under-the-table "sub-contracting". Income from land contractual activities and redistribution of the income are lack of transparency.

\subsection{Trend of detriment to farmers' interest from non-farming construction use of land}

At present, most non-farming construction land is from national acquisition without the consideration to the differences of public welfare and commercial use. Land expropriation and land offer are based on dual-track system, namely, land expropriation keeps the coercive tradition of the planned economy system; while land offer adopted the market economy system and is compensated. Local government profits from selling land. With ever increased real estate development, constructions such as university towns, development zones, small towns, have gradually grown to a white hot stage. Land expropriation gets out of control, "land siege" keeps escalating. Farmers can not be compensated fairly with the so called "one finalized deal". In addition, the compensation is often short when it comes to farmers due to multi-layered commission fees by middle men. Farmers are often compensated by a little relocation fee only. Land acquisition cost has reached RMB1,050,000-1,200,000 per hectare, while the farmers are only paid RMB150,000 per hectare. It is like a rubbery to farmers. Many farmers lost their lands, lost stable input from the land for living, eventually become drifters and threaten the social stability.

\section{Principles for standardizing and regulating the right transfer of land}

The land's right transfer matters not only to farmers' vital interests, but also to the agriculture development and the stability of rural area. It belongs to the domain of adjustment of production relation, has strong political implication and broad reach, and is with serious complications and conflicts. Therefore it is necessary to have a set of well defined principles and systematically develop the framework.

\subsection{Essential principles for transfer right of land in rural area}

The basic principles for improving fairness in land transfer are to correctly excise the policies and laws related to land, improve the utilization/allocation efficiency of rural land resource, ensure to protect farmers' legal rights, as well as correctly solve the intricate subtle issues among these issues. The major premise for warranting the fairness in transferring land is the following the Party's land policy in rural area. The essential task is improving allocation efficiency of land resource. The ultimate goal of facilitating land transfer is to protect farmers' legal rights and interests. All of these are consistent with the slogan "Regarding Peasants as Core".

2.1.1 Follow the principle of family-based land contractual right and maintain the principle for 30 years

This is the principle fundamentally protecting farmers' current interest and long term interest. It is the policy foundation for the stability of rural area. Under this principle, the land transfer is only the right of utilization. Farmers will not lose ownership due to the right transfer. The transfer of right is not compensated with one payment; neither is at a permanently fixed rate. Farmers should have a stable income permanently. 


\subsubsection{Follow the principle of farmers collectively owned land}

30 years' contractual right grants farmers real property right. This is a quasi-property right, with which farmers enjoy the right of possessing, using, profiting from and dealing of land. It is only when farmers are granted full contractual right without any compromise that an effective land transfer system could be possibly established, become an essential element of market, and lead to improved allocation efficiency of land.

2.1.3 Follow the principle of "farmers as focal point" in the land transfer

Farmers' opinion has to be respected in the land transfer. The focal point of land transfer is farmers. Transfer should mainly among farmers. Income should be shared among farmers. The principle of farmers as the major practitioners is the natural consequence of following above two principles. It is also the realization of protecting farmers' land interest (Zhang, Aiyun, 2003, p. 12-15).

\section{Strengthen the standardized administration and regulation of the land transfer}

The land transfer involves the interests of land owner, land user, intermediary organization and others. Land transfer should be preceded according to standardized and regulated procedure. With the land transfer contractual concept established, parties should sign an authorized transfer contract qualifying the transfer form, the amount, the term, the condition of the transfer, the rights of relevant parties. The contract has to be notarized by relevant authorities. It is necessary to establish a broad registration system for land transfer, standardize and regulate the transfer administration.

\subsection{Promote leasing while allow diversified forms of land transfer}

Leasing is simple and easy to practice. It is easier for farmers to accept. It is also a form popular over the world. It is even more suitable to our country where land purchase/selling is not allowed and land right transfer is allowed. Leasing fee is also more understanding and easier to be regulated comparing to the "compensation of land right transfer". The term for land transfer should not be too long since the value of land in far horizon is difficult to estimate, especially with the expectation of rural economy development and growth of land market. Long term transfer makes it harder to protect farmers' long term interest.

\subsection{Grow aggressively the intermediary organization for the land transfer}

Establishing a market for transfer the right of using land is imperative in the shift of land transfer system. Perfecting intermediary organizations is the key in establishing the market of land right transfer. Intermediary organizations bridge the parties of land suppliers and the parties of land demanders. Counties may establish such intermediary organizations associated with agricultural economic centers. The intermediary organizations may be responsible for bridging and managing land right transfer, including planning and scheduling, collecting and broadcasting information of supply and demand, promoting specific contracts, regulating and standardizing transfer procedure, guiding through procedural process, coordinating among different parties and providing services.

\subsection{Accurately position the local authorities' roles}

The local authorities are the administrators for the rural land. They are responsible for supervising the proper utilization of land resource, the transfer of land-use right, and controlling the dynamic balance of land supply and demand. They should not adjust the flow of land resource transfer with authority power, interfere with and even take over the right of land from farmers. Therefore, local authorities should position themselves as enhancing management and providing service. Local authorities should do a good job in qualification examination, contract notification, archive management and dynamic supervision. Local authorities should provide information and provide services such as bridging, organizing, coordinating, etc. Local authorities should plan strategically the long term land utilization and transfer, land interconnection and converging, construction and improvement of agricultural land infrastructure, and create a better environment for facilitating land transfer (Gai, Guoqiang, 2001, p. 20-23). 


\subsection{Protect farmers' legal interests in the non-farming land acquisition}

Land is a scarce resource that can not be regenerated. With the development of market economy, land processes not only the function of providing living income, but also the function of property with ever increasing value. To non-agriculture land transfer, we have to distinguish national public welfare construction and commercial construction. For national public welfare construction, it is proper to expropriate the farmers' land, but the compensation on rural land acquisition should benefit farmers instead of being exploited by middlemen. For commercial construction land, it is not proper to buy out the farmers' land, leasing of land or partial ownership should be adopted so that farmers may have long-term stable income.

\subsection{Accelerate the legislation of the land transfer}

Details should be established in the laws and regulations of land lease and contract in rural area as early as possible. It is imperative to establish the laws and regulations for rural area land transfer, which governs the definition of the rights of farmers over land, the qualification of the compensation standard and income sharing for the land right transfer, management of land transfer, solution to the confrontation and conflicts that local authorities have difficulties to address and solve. Rural land transfer process should be fitted under the legal framework of law through thoughtful study and investigation. Law should be used to protect long term stability of agricultural economy, and protect healthy and orderly growth of the interest of land contract and land right transfer.

\section{References}

Gai, Guoqiang. (2001). Creation in land system in the course of agricultural modernization. Journal of Shandong Agricultural University, 2, 20-23.

Zhang, Aiyun. (2003). Thoughts on propelling the circulation of rural land-use right. Tribune of Study, 7, $12-15$. 